\title{
EFFECTIVENESS OF TWO DIFFERENT EVAPORATIVE COOLING SYSTEMS IN A SYNTHETIC WARMED AIR SPACE
}

\section{El-said M. Khalifa ${ }^{1}$, Said E. AbouZaher ${ }^{2}$ and Hanaa A. Elmoghazy ${ }^{3}$}

\section{ABSTRACT}

Heat stress inside farm structures such as animals and poultry farms in addition to greenhouses is one of the major problems facing the producers in this field. Such problem is virtually occurred at the time of hot waves during which just ventilation process could not the appropriate action and the need for an immediate step in is urgent. Evaporative cooling systems serve as a one solution to alleviate heat stress and contribute in controlling the environment inside the structure. Therefore the present study has aimed to stand on the effectiveness of two different evaporative cooling systems namely pad-fan and misting systems in a synthetic warmed air space. An artificial ventilation system was tested simultaneously to emphasize the necessity of cooling the ventilation air. Experimental setup of three similar greenhouse models representing the synthetic warmed air space each was equipped with a one system and instruments were installed on a roof of a dwelling at Ariamoon village near Kafr elsheikh city, Kafr elsheikh Governorate, Egypt $\left(31.18^{\circ} \mathrm{N}, 30.91{ }^{\circ} \mathrm{E}\right)$. Pad-fan system was investigated at 10 and 5 $\mathrm{cm}$ pad thickness of a manually constructed pad material made of a balanced (1:1) mixture of rice straw and palm leaf fibers (kerina). Misting system was investigated at 207 and $103 \mathrm{kPa}$ (30 and $15 \mathrm{psi}$ ) nozzle pressure. Different airflow rate $(Q)$ levels ranged from 0.042 to $0.155 \mathrm{~m}^{3} / \mathrm{s}$ were applied. Air temperature $(T)$ and relative humidity $(R H)$ were detected on hourly basis for three days as repetitions for each treatment. To stand on the effectiveness and cooling potential of both evaporative cooling systems, temperature reduction $(\Delta T)$, saturation

\footnotetext{
${ }^{1}$ Professor, Agric. Eng. Dept., Faculty of Agriculture, Kafrelsheikh University, Egypt.

${ }^{2}$ Assistant Professor, Agric. Eng. Dept., Faculty of Agriculture, Kafr elsheikh University, Egypt.

${ }^{3}$ Graduate Student, Agric. Eng. Dept., Faculty of Agriculture, Kafr elsheikh University, Egypt. - said.abouzaher@agr.kfs.edu.eg.
} 
efficiency (SE), Specific temperature reduction $(\Delta T / Q)$, unit evaporative cooler performance (Unit ECP) and water consumption were calculated and showed. The results revealed a $\Delta T$ ranged from 0.4 to $2.12^{\circ} \mathrm{C}$ and from 0.38 to $3.49^{\circ} \mathrm{C}$ for pad-fan and misting systems respectively. $R H$ of the cooled air ranged from 90.8 to $98.6 \%$ and from 88.9 to $97.97 \%$ for pad-fan and misting systems respectively. SE, $\triangle T / Q$ and Unit ECP beyond $78 \%, 41{ }^{\circ} \mathrm{C} . \mathrm{s} / \mathrm{m}^{3}$ and $10 \mathrm{~kW} /{ }^{\circ} \mathrm{C}$ respectively were reached with the most higher values belong to misting system. The artificial ventilation system caused a temperature rise and failed at least to keep the temperature as it is outside. Accordingly and under the current experimental conditions the misting system revealed to have the merit in cooling effectiveness. In addition, the attractive advantage of saving water and its appropriateness in playing a considerable role in irrigation technology under the protected agriculture.

Key words: Evaporative cooling, pad and fan, misting, saturation efficiency, greenhouses.

\section{INTRODUCTION}

$\mathrm{E}$ vaporative cooling is wide spreading in controlling the environment inside agricultural structures. Its systems include fanpad, misting and fogging systems. Each is affected by numerous factors such as pad material, density, configuration, dimensions and airflow rate regarding pad-fan system, nozzles pressure, discharge and air velocity for misting and fogging systems.

Misra and Ghosh (2018) represented a comprehensive review of evaporative cooling technologies for greenhouses. Their review revealed that, the selection of an appropriate evaporative cooling system depends on greenhouse design and construction. The evaporative cooling was very much effective to achieve better cooling performance inside greenhouses. They recommended some innovative cooling ideas for greenhouse applications such as evaporative cooling system with solar chimney assisted ventilation. Darwesh et al. (2007) studied the effect of pad material, thickness and pad face air velocity on the performance of the evaporative cooling system. Rice straw and palm leaf fibers (Kerina) were used as different pad materials. 3, 6, 10,15 cm pad thicknesses and 0.3, $0.5,1.05 \mathrm{~m} / \mathrm{s}$ air velocities were studied. Their results showed an increase 
in temperature reduction by increasing pad thickness. They concluded that rice straw pad was better than palm leaf fibers pad in reducing air temperature. It achieved the highest average value of unit evaporative cooler performance more than $75 \mathrm{~kW} /{ }^{\circ} \mathrm{C}$ at $15 \mathrm{~cm}$ pad thickness and 1.05 $\mathrm{m} / \mathrm{s}$ pad face air velocity. Abdallah and Basiouny (2008) showed a diurnal trend of the temperature reduction. There experiments revealed a temperature reduction ranged from near 3 to more than $7{ }^{\circ} \mathrm{C}$ for the vertical pad. While Tayal et al. (2010) studied three pad materials made of flax plant residues, Luffa plant residues, and a combination of both. Each pad material was tested under three thicknesses 4, $8,12 \mathrm{~cm}$ and three pad face air velocities, $0.45,0.65$ and $0.90 \mathrm{~m} / \mathrm{s}$. They mentioned that, the highest mean cooling efficiency was for flax followed by Luffa followed by the combination. They concluded that increasing pad thickness and decreasing air velocity lead to increase cooling efficiency. Dayioglu and Silleli (2015) conducted a performance analysis of a padfan cooling system within a greenhouse. They found that the hourly average cooling effect and cooling efficiency were $6.96^{\circ} \mathrm{C}$ and $76.8 \%$ respectively. Shah (2015) investigated the performance of different pad materials ( rigid cellulose, PVC, grass and fabric material ), air and water flow rate on saturation efficiency and cooling capacity. He found that the cellulose material gives the highest saturation efficiency of about $93 \%$ while fabric material gives the lowest one of about $44 \%$. The cooling capacity increases with airflow rate and ranged from 1 to $5 \mathrm{~kW}$ for different materials. Misra and Ghosh (2017) studied performance of a greenhouse system surrounded by shallow water ponds and floating wetted surfaces under dual ventilation mode. They predicted the greenhouse temperatures using thermal models with or without evaporative cooling under natural ventilation as well as fan-induced ventilation. They observed that greenhouse temperature could be reduced by $3-6^{\circ} \mathrm{C}$ lower than that of the ambient temperature when saturation efficiency and shading were $70 \%$ and $75 \%$ respectively. Shen and Chen (2012) evaluated cooling efficiencies of misting system with mechanical fans in an Oncidium greenhouse. They tested cooling ability in different interval times. Their results showed that when the misting time was too short or the misting inactive period was too long, the efficiency was 
decreased. The misting intervals of $3 \mathrm{~min}$ on to $3 \mathrm{~min}$ off or $5 \mathrm{~min}$ on to 5 min off had the higher efficiency.

Their cooling technique can keep the interior air temperature lower than that of outside one. Heidarinejad et al. (2019) studied the effect of a water mist system on a chiller COP under various orientations of the spray nozzle. Their simulation study pointed to an increase in COP due to the cooling effect of the used misting system. Lopez et al. (2013) evaluated the microclimate and airflow inside a Mediterranean greenhouse under roof natural ventilation and artificial ventilation by means of sonic anemometry. Their experiments were carried out under a moderate low wind speed of about $1.8 \mathrm{~m} / \mathrm{s}$ and $4.0 \mathrm{~m} / \mathrm{s}$ respectively. Artificial ventilation for the greenhouse was supplemented by two horizontal airflow fans. They found a temperature rise in both ventilation systems. They mentioned that this result means that there was a difficulty of heat to leave the greenhouse. Accordingly evaporative cooling system represents a promising technique in diminishing heat stress through temperature reduction. Therefore the main objective of the present study was to stand on the effectiveness of two different evaporative cooling systems in a synthetic warmed air space. Many parameters were introduced to judge the effectiveness of studied evaporative cooling systems under different investigated technical specifications.

\section{MATERIALS AND METHIODS}

\section{Materials and setup:}

Main experiments of the present study were conducted during august and September 2014 in Ariamoon village near Kafr elsheikh city, Kafr elsheikh Governorate, Egypt $\left(31.18^{\circ} \mathrm{N}, 30.91^{\circ} \mathrm{E}\right)$. Three gable roof greenhouse models were fabricated and oriented East-West and used to represent the warmed air space. Each model has $3 \mathrm{~m}$ and $2 \mathrm{~m}$ total length and total width respectively. The height was $2 \mathrm{~m}$ and $2.5 \mathrm{~m}$ at side walls (eave) at the center (ridge) respectively as shown in Figure 1. The greenhouse structural frame was formed of welded steel angles $(30 \times 30$ $\mathrm{mm}$ ) having a door area of about $2 \times 0.7 \mathrm{~m}$ located in the east side of each model. Each greenhouse was covered with a single polyethylene sheet 50 $\mu \mathrm{m}$. Two different cooling systems namely pad-fan system and misting ones along with an artificial ventilation system each was installed in one 
of the greenhouse models. Regarding pad- fan system two different pad thicknesses of $10,5 \mathrm{~cm}$ were investigated. Two nozzles pressure namely $207 \mathrm{kPa}(30 \mathrm{psi})$ and $103 \mathrm{kPa}(15 \mathrm{psi})$ belong to misting system were investigated as well. Three similar suction fans $\left(26 \mathrm{In}^{-} 35_{\text {Exit }} \pm 5\right) \mathrm{W}$ rated power, $30 \mathrm{~cm}$ diameter, and $\mathrm{Q}=\left(720_{\mathrm{In}^{-}}-975_{\mathrm{Exit}}\right) \mathrm{m}^{3} / \mathrm{h}$ each was fixed on the east wall of a greenhouse model. However, the fan was conducted to a purchased ceiling fan regulator and calibrated to get the capability of changing airflow rate within each system. For each system six different air velocities as indicated in Table 1 were studied.
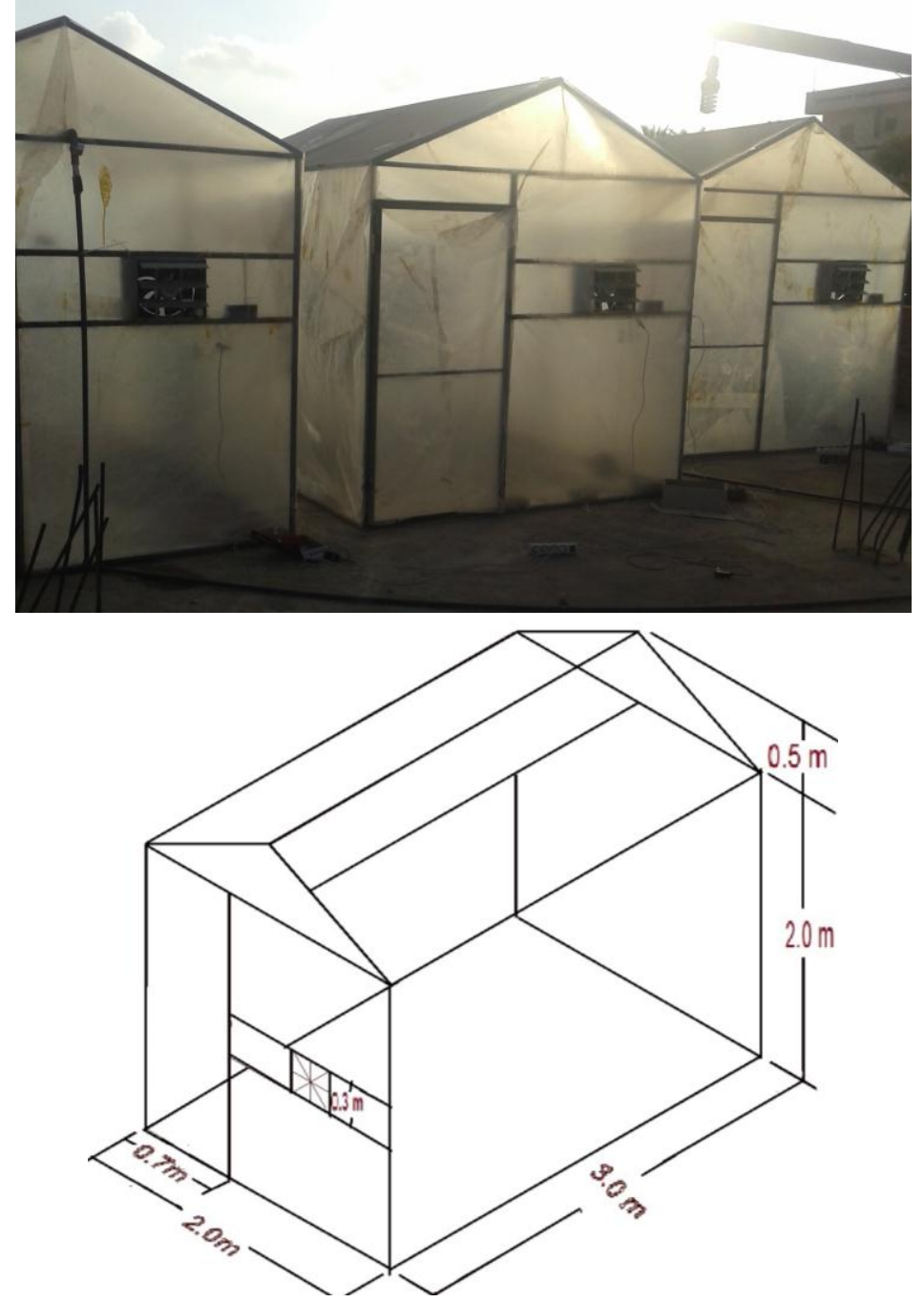

Figure 1: A photography and schematic diagram of the greenhouse model 
These tabulated air velocity vales were obtained from a direct calibration procedure to the used fan under each treatment. However the fixation of the air velocity levels to all treatments was an awkward process. The three systems were operated simultaneously throughout a period of 11 hours daily from 8 am to $7 \mathrm{pm}$ and repeated for three days of each treatment.

Table 1: Different ranges of air velocity and corresponding airflow rate for each system:

\begin{tabular}{|c|c|c|c|c|c|c|c|}
\hline \multicolumn{3}{|c|}{ Pad system } & \multicolumn{3}{c|}{ Misting system } & \multicolumn{2}{c|}{$\begin{array}{c}\text { Artificial } \\
\text { ventilation system }\end{array}$} \\
\hline $\begin{array}{c}\text { Pad } \\
\text { thickness } \\
(\mathbf{c m})\end{array}$ & $\begin{array}{c}\text { Air } \\
\text { velocity } \\
(\mathbf{m} / \mathbf{s})\end{array}$ & $\begin{array}{c}\text { Airflow } \\
\text { rate } \\
\left(\mathbf{m}^{3} / \mathbf{s}\right)\end{array}$ & $\begin{array}{c}\text { Nozzle } \\
\text { pressure } \\
(\mathbf{k P a})\end{array}$ & $\begin{array}{c}\text { Air } \\
\text { velocity } \\
(\mathbf{m} / \mathbf{s})\end{array}$ & $\begin{array}{c}\text { Airflow } \\
\text { rate } \\
\left(\mathbf{m}^{3} / \mathbf{s}\right)\end{array}$ & $\begin{array}{c}\text { Air } \\
\text { velocity } \\
(\mathbf{m} / \mathbf{s})\end{array}$ & $\begin{array}{c}\text { Airflow } \\
\text { rate } \\
\left(\mathbf{m}^{\mathbf{3}} / \mathbf{s}\right)\end{array}$ \\
\hline \multirow{3}{*}{10} & 2.2 & 0.155 & & 2.1 & 0.148 & 1.9 & 0.13414 \\
\cline { 2 - 5 } & 1.6 & 0.113 & \multirow{2}{*}{207} & 1.5 & 0.106 & 1.4 & 0.09884 \\
\cline { 2 - 5 } \cline { 6 - 8 } & 1.0 & 0.071 & & 0.9 & 0.064 & 0.8 & 0.05648 \\
\hline \multirow{3}{*}{5} & 1.7 & 0.120 & & 1.6 & 0.122 & 1.4 & 0.09884 \\
\cline { 2 - 5 } & 1.2 & 0.085 & \multirow{2}{*}{103} & 1.1 & 0.078 & 0.9 & 0.06354 \\
\cline { 2 - 5 } & 0.7 & 0.049 & & 0.6 & 0.043 & 0.5 & 0.03530 \\
\hline
\end{tabular}

\section{Investigated Systems:}

\section{Pad and fan system:}

Pad system consisted of a wood frame $(0.3 \mathrm{~cm}$ thickness $)$ having the dimensions of $2 \mathrm{~m} \times 1 \mathrm{~m}$ to contain the pad material. Water tray was fixed above the pad through its longitudinal axis with holes along the tray in 3 lines and the distance between each hole and the other $1 \mathrm{~cm}$. To guarantee a uniformly water flow rate all over the pad in the transverse direction a thin pad strip having $3 \mathrm{~cm}$ thickness, $2 \mathrm{~m}$ long and 5 or $10 \mathrm{~cm}$ width to fit the studied pad thickness was used. It was located horizontally along the main pad to help in distribution water at the same rate along the pad surface. A drainage tray was also provided in the bottom of the pad. The pad material were selected to be a balanced (1:1) mixture of rice straw (RS) and palm leaf fibers (PLF) and having a density of $32 \mathrm{~kg} / \mathrm{m}^{3}$. The rice straw had cut within a range of $10-30 \mathrm{~cm}$ length and mixed with palm leaf fibers to form the pad material by the aid of wire net as a frame to be filled with the pad material uniformly distribution manner. The 
frame was adjusted to contain the investigated pad thickness, namely 5 and $10 \mathrm{~cm}$. A water tank and a small pump $\left(0.5 \mathrm{~kW}, \mathrm{Q}=10\right.$ to $\left.40 \mathrm{~m}^{3} / \mathrm{h}\right)$ attached to the tank were used for the purpose of pumping water to the pad. The water pump lifted water to the distribution system from where it trickled down by gravity to the pad. The excess water, which was not vaporized, was collected from the bottom tray under the pad and returned back manually to the water tank in such a manner by which the water consumption could be determined. One of the similar fans was fixed on the east wall as mentioned before to complete the pad-fan system. Figure 2 (A) illustrates a schematic of pad fan system.

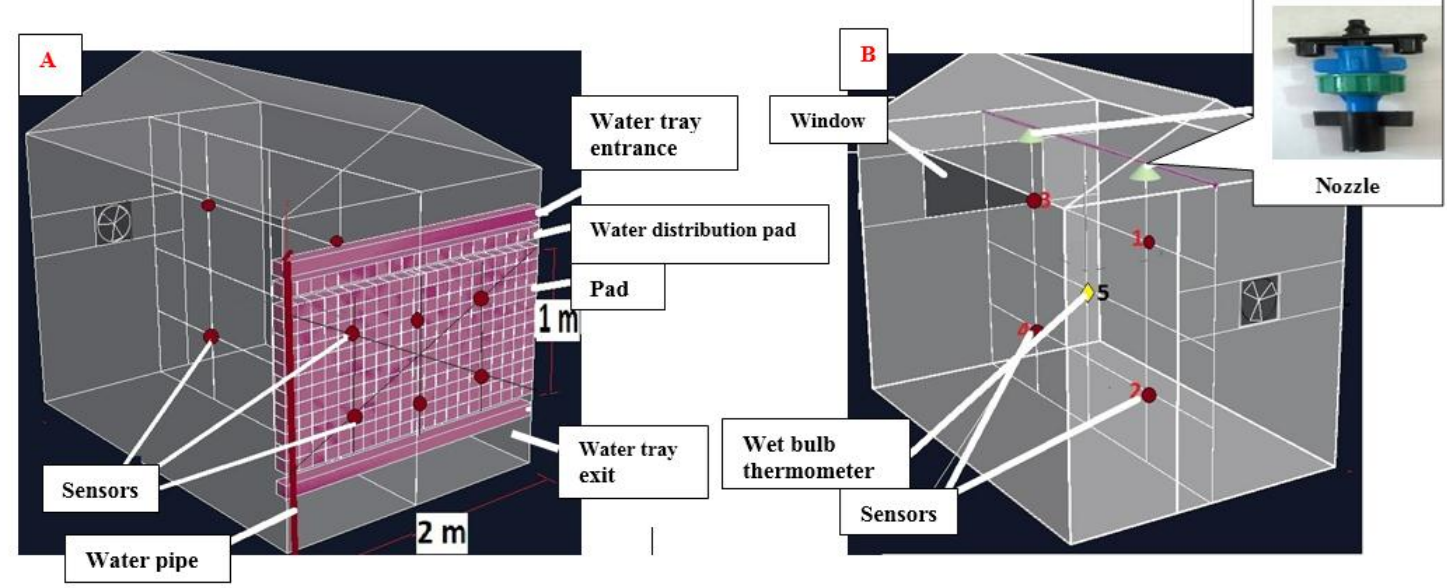

Figure 2: Schematic diagram of (A) pad - fan system, (B) misting system and a photo of the used nozzle

\section{Misting system:}

Misting system was accomplished by using two nozzles as indicted in Figure 2 (B). Nozzles were fixed in the greenhouse model at 0.75 and $2.25 \mathrm{~m}$ from the door at $2 \mathrm{~m}$ height. West wall of the greenhouse model was equipped with an opened window $(1 \times 0.5 \mathrm{~m})$ at $1.25 \mathrm{~m}$ height from the floor surface as an air entrance. A similar fan was fixed on the east wall to represent the artificial ventilation. Water was pressured to the nozzles by a pump $(0.33 \mathrm{~kW}, \mathrm{Q}=0.38 \mathrm{~m} / \mathrm{h})$. A manual valve was used to control the water flow rate and in turn water stream pressure flowing to the nozzles. Two pressure levels of $207 \mathrm{kPa}$ and $103 \mathrm{kPa}$ was investigated. 


\section{Artificial ventilation system:}

The artificial ventilation system consisted of a similar greenhouse model equipped only with a similar fan in the east side. In addition an opened window $(1 \times 0.5 \mathrm{~m})$ at $1.25 \mathrm{~m}$ height from the floor surface in the west wall to allow the ambition air to get in.

\section{Measurements and parameters calculation:}

\section{Air temperatures and relative humidity:}

Two ordinary thermometers (dry and wet) used for measuring the outside ambient dry and wet-bulb temperatures. For each system model four LM35 temperature sensors were employed and disturbed two at a height of $0.5 \mathrm{~m}$ from the floor (lower level) and the remainder two at a height of $1.5 \mathrm{~m}$ from the floor (Upper level) to measure dry-bulb temperature inside the tested model. Six LM35 temperature sensors were devoted to measure dry bulb temperature of the air just exits from the pad. Another wet-bulb thermometer was used to detect the wet-bulb temperature inside the misting system model as shown in Figure 2 (B). The data was taken every 60 minutes. A digital psychometric chart was used to determine the required psychometric properties such as relative humidity $(\mathrm{RH})$ and specific volume. (https://hvac-library.blogspot.com/p/digital-psychrometric-chart.html)

\section{Performance parameters:}

Hourly performance parameter namely temperature reduction $(\Delta T)$, saturation efficiency $(\mathrm{SE})$, specific temperature reduction $(\Delta \mathrm{T} / \mathrm{Q})$, evaporative cooler performance unit (Unit ECP) and water consumption for pad-fan system and misting system were calculated. Regarding the artificial ventilation system only hourly temperature and relative humidity were introduce to judge the system.

\section{Temperature reduction $(\Delta T)$ :}

Temperature reduction $(\Delta \mathrm{T})$ was calculated for each experimental treatment by using the following equation:

$$
\Delta \mathrm{T}=\mathrm{T}_{\mathrm{db}}-\mathrm{T}_{\mathrm{C}}
$$

Where $\Delta \mathrm{T}$ is the temperature reduction $\left({ }^{\circ} \mathrm{C}\right), \mathrm{T}_{\mathrm{db}}$ is the dry-bulb temperature of the ambient air $\left({ }^{\circ} \mathrm{C}\right)$ and $\mathrm{T}_{\mathrm{c}}$ is the dry-bulb temperature of the cooled air inside greenhouse $\left({ }^{\circ} \mathrm{C}\right)$. 


\section{Saturation Efficiency (SE):}

To judge the evaporative cooling system effectiveness the saturation efficiency was determined for each treatment throughout the operating day time period. It can be calculated as follows Darwesh et al. (2007), Shen and Chen. (2012) :

$$
\mathrm{SE}=\left(\mathrm{T}_{\mathrm{db}}-\mathrm{T}_{\mathrm{C}}\right) /\left(\mathrm{T}_{\mathrm{db}}-\mathrm{T}_{\mathrm{wb}}\right)
$$

Where SE is the saturation efficiency (dimensionless), $\mathrm{T}_{\mathrm{wb}}$ is the wet-bulb temperature of the cooled air inside greenhouse $\left({ }^{\circ} \mathrm{C}\right)$ and $\left(\mathrm{T}_{\mathrm{db}}-\mathrm{T}_{\mathrm{wb}}\right)$ is the wet bulb depression $\left({ }^{\circ} \mathrm{C}\right)$

\section{Specific temperature reduction $(\Delta T / Q)$ :}

To evaluate the evaporative cooling system in reducing dry bulb temperature under different airflow rates in the greenhouse models due to the variation in airflow rate applied in each treatment, it was considered to determine the temperature reduction per a unit of airflow rate.

This suggested parameter was decided to cope with the variation in airflow rate among all treatments and it was calculated using the following formulae:

$$
\mathrm{Q}=v^{*} \mathrm{~A} / \mathrm{Q}=\left(\mathrm{T}_{\mathrm{db}}-\mathrm{T}_{\mathrm{C}}\right) / \mathrm{Q}
$$

Where $Q$ is the airflow rate $\left(\mathrm{m}^{3} / \mathrm{s}\right), v$ is the air velocity $(\mathrm{m} / \mathrm{s})$ and $A$ is the fan opening cross section area $\left(\mathrm{m}^{2}\right)$

\section{Evaporative Cooler Performance Unit (Unit ECP):}

To explore the absolute performance under different conditions, a measuring unit namely evaporative cooler performance unit (Unit ECP) that expresses the cooling effect in terms of energy per a unit time and per a unit wet bulb depression. It can be calculated as follows (Darwesh et al. (2007)):

$$
\text { Unit } \mathrm{ECP}=\left(\mathrm{Q} / \mathrm{V}_{\mathrm{s}}\right) * \mathrm{SE} * \mathrm{Cp} \text { air }
$$

Where Unit ECP is the unit evaporative cooler performance $\left(\mathrm{kW} /{ }^{\circ} \mathrm{C}\right), \mathrm{V}_{\mathrm{S}}$ is the specific volume of air $\left(\mathrm{m}^{3} / \mathrm{kg}\right)$ and $\mathrm{Cp}_{\text {air }}$ is the specific heat of air $\left(1.005 \mathrm{~kJ} / \mathrm{kg} .{ }^{\circ} \mathrm{C}\right)$.

\section{Water Consumption:}

Water consumption was determined by measuring the change in water volume within a known water tank. This was done through the 11 
operating hours. Hourly rate of water consumption was calculated as an hourly average

\section{RESULTS AND DISCUSSION}

\section{Hourly air Temperature (T) and Relative Humidity (RH):}

Hourly air temperature and relative humidity outside and inside the three investigated systems at different treatments throughout the daily operating period are illustrated in Figure 3. Both pad-fan and misting evaporative cooling systems were capable to achieve a reasonable air cooling having the common diurnal trend. The artificial ventilation system caused a temperature rise and failed at least to keep the temperature as it is outside. This was due to the predominant effect of the greenhouse solar energy gain in relation to air exchange rate which was the lower one compared with both evaporative cooling systems. Therefore this system was not discussed in the next sections in which cooling parameters were explored. The average values of maximum and minimum air temperatures outside and inside the three investigated systems at different treatments are listed in Table 2. Whereas the outside air temperature ranged from 26.0 to $40^{\circ} \mathrm{C}$ the average cooled air temperature ranged from 25.18 to $38.66{ }^{\circ} \mathrm{C}$ and from 25.29 to $36.70{ }^{\circ} \mathrm{C}$ for pad-fan system and misting system respectively. Regarding the artificial ventilation system, the inside air temperature ranged from 30.37 to $43.77{ }^{\circ} \mathrm{C}$. The average values of maximum and minimum relative humidity outside and inside the three investigated systems at different treatments are shown in Table 3. Outside relative humidity ranged from 81.61 to $95.10 \%$. The average inside air relative humidity ranged from 90.80 to $98.60 \%$, from 88.90 to $97.97 \%$ and from 45.57 to $82.10 \%$ for pad-fan system, misting system and the artificial ventilation system respectively. As it is well known the evaporative cooling process increases relative humidity as the case in both cooling systems. The impact of both pad-fan and misting evaporative cooling systems on the relative humidity level was almost the same. They caused an increase in relative humidity as it was expected by the range of about 2.02 to $12.5 \%$ and 0.2 to $13.49 \%$ for both systems respectively. On the other hand for the artificial ventilation system caused a reduction in relative humidity since the inside air was sensibly heated through the greenhouse effect. A decrease ranged from 12.69 to $42.78 \%$ was 
occurred in the artificial ventilation system. However, the pad-fan system contributes in raising relative humidity more than the misting system.
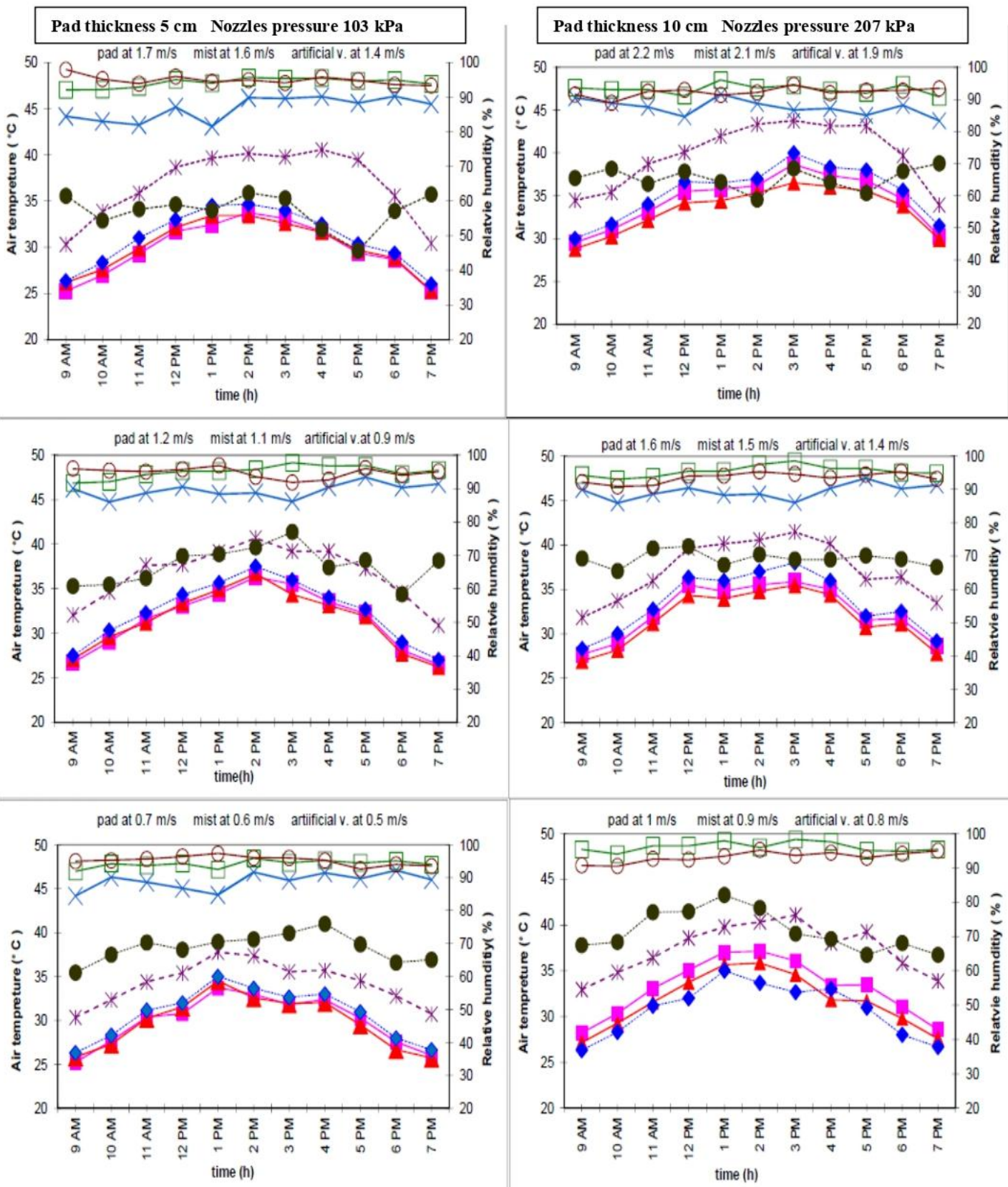

Figure 3: Hourly air temperature and relative humidity outside and inside the three investigated systems at different treatments throughout the daily operating period. 
Table 2: The average values of maximum and minimum air temperatures outside and inside the three investigated systems at different treatments.

\begin{tabular}{|c|c|c|c|c|c|c|c|c|c|c|c|c|}
\hline \multirow{3}{*}{\multicolumn{2}{|c|}{$\begin{array}{c}\begin{array}{c}\text { Outside } \\
\text { conditions }\end{array} \\
\begin{array}{c}\text { Air' } \\
\text { temperature } \\
\left({ }^{\circ} \mathrm{C}\right)\end{array}\end{array}$}} & \multicolumn{11}{|c|}{ Inside conditions } \\
\hline & & \multicolumn{4}{|c|}{ Pad- fan system } & \multicolumn{4}{|c|}{ Misting system } & \multicolumn{3}{|c|}{$\begin{array}{c}\text { Artificial ventilation } \\
\text { system }\end{array}$} \\
\hline & & \multirow{2}{*}{$\begin{array}{c}\text { Pad } \\
\text { thickness } \\
\text { (cm) }\end{array}$} & \multirow[t]{2}{*}{$\begin{array}{c}\text { Air } \\
\text { velocity } \\
(\mathrm{m} / \mathrm{s})\end{array}$} & \multicolumn{2}{|c|}{$\begin{array}{c}\text { Air" } \\
\text { temperature } \\
\left({ }^{\circ} \mathrm{C}\right)\end{array}$} & \multirow{2}{*}{$\begin{array}{c}\text { Nozzles } \\
\text { pressure } \\
\text { (kPa) }\end{array}$} & \multirow[t]{2}{*}{$\begin{array}{c}\text { Air } \\
\text { velocity } \\
(\mathrm{m} / \mathrm{s})\end{array}$} & \multicolumn{2}{|c|}{$\begin{array}{c}\text { Air" } \\
\text { temperature } \\
\left({ }^{\circ} \mathrm{C}\right)\end{array}$} & \multirow[t]{2}{*}{$\begin{array}{c}\text { Air } \\
\text { velocity } \\
(\mathbf{m} / \mathbf{s})\end{array}$} & \multicolumn{2}{|c|}{$\begin{array}{c}\text { Air } \\
\text { temperature } \\
\left({ }^{\circ} \mathrm{C}\right)\end{array}$} \\
\hline Max & Min & & & Max & Min & & & Max & Min & & Max & Min \\
\hline 40.00 & 30.00 & \multirow{3}{*}{10} & 2.2 & 38.66 & 29.53 & \multirow{3}{*}{207} & 2.1 & 36.51 & 28.80 & 1.9 & 43.77 & 33.93 \\
\hline 38.01 & 28.30 & & 1.6 & 35.88 & 27.68 & & 1.5 & 35.47 & 26.96 & 1.4 & 41.46 & 31.82 \\
\hline 38.00 & 28.70 & & 1.0 & 37.17 & 28.20 & & 0.9 & 35.88 & 27.17 & 0.8 & 41.09 & 32.94 \\
\hline 34.67 & 26.01 & \multirow{3}{*}{ J } & 1.7 & 33.73 & 25.18 & \multirow{3}{*}{103} & 1.6 & 33.45 & 25.29 & 1.4 & 40.58 & 30.30 \\
\hline 37.50 & 27.01 & & 1.2 & 36.34 & 26.52 & & 1.1 & 36.70 & 26.22 & 0.9 & 40.67 & 30.88 \\
\hline 35.01 & 26.33 & & 0.7 & 33.72 & 25.27 & & 0.6 & 34.51 & 25.74 & 0.5 & 37.39 & 30.37 \\
\hline
\end{tabular}

Table 3: The average values of maximum and minimum relative humidity outside and inside the three investigated systems at different treatments.

\begin{tabular}{|c|c|c|c|c|c|c|c|c|c|c|c|c|}
\hline \multirow{3}{*}{\multicolumn{2}{|c|}{$\begin{array}{c}\begin{array}{c}\text { Outside } \\
\text { conditions }\end{array} \\
\begin{array}{c}\text { Relative } \\
\text { humidity } \\
(\%)\end{array}\end{array}$}} & \multicolumn{11}{|c|}{ Inside conditions } \\
\hline & & \multicolumn{4}{|c|}{ Pad- fan system } & \multicolumn{4}{|c|}{ Misting system } & \multicolumn{3}{|c|}{$\begin{array}{c}\text { Artificial ventilation } \\
\text { svstem }\end{array}$} \\
\hline & & \multirow{2}{*}{$\begin{array}{c}\text { Pad } \\
\text { thickness } \\
(\mathbf{c m})\end{array}$} & \multirow{2}{*}{$\begin{array}{c}\text { Air } \\
\text { velocity } \\
(\mathbf{m} / \mathbf{s})\end{array}$} & \multicolumn{2}{|c|}{$\begin{array}{c}\text { Relative } \\
\text { humidity } \\
(\%)\end{array}$} & \multirow{2}{*}{$\begin{array}{c}\text { Nozzles } \\
\text { pressure } \\
\text { (kPa) }\end{array}$} & \multirow{2}{*}{$\begin{array}{c}\text { Air } \\
\text { velocity } \\
(\mathbf{m} / \mathbf{s})\end{array}$} & \multicolumn{2}{|c|}{$\begin{array}{c}\text { Relative } \\
\text { humidity } \\
(\%)\end{array}$} & \multirow{2}{*}{$\begin{array}{c}\text { Air } \\
\text { velocity } \\
(\mathbf{m} / \mathbf{s})\end{array}$} & \multicolumn{2}{|c|}{$\begin{array}{c}\text { Relative } \\
\text { humidity } \\
\text { (\%) }\end{array}$} \\
\hline $\operatorname{Max}$ & Min & & & Max & Min & & & Max & Min & & Max & Min \\
\hline 91.61 & 83.41 & \multirow{3}{*}{10} & 2.2 & 96.01 & 90.80 & \multirow{3}{*}{207} & 2.1 & 94.67 & 88.90 & 1.9 & 70.06 & 58.80 \\
\hline 93.41 & 86.01 & & 1.6 & 98.60 & 93.10 & & 1.5 & 95.47 & 90.92 & 1.4 & 72.90 & 65.50 \\
\hline 95.10 & 89.70 & & 1.0 & 98.31 & 94.00 & & 0.9 & 95.32 & 90.63 & 0.8 & 82.10 & 64.68 \\
\hline 90.28 & 81.61 & \multirow{3}{*}{5} & 1.7 & 95.69 & 92.14 & \multirow{3}{*}{103} & 1.6 & 97.97 & 93.80 & 1.4 & 62.34 & 45.57 \\
\hline 94.60 & 84.10 & & 1.2 & 97.70 & 91.60 & & 1.1 & 96.91 & 91.83 & 0.9 & 76.95 & 58.34 \\
\hline 92.22 & 84.48 & & 0.7 & 95.83 & 91.92 & & 0.6 & 97.34 & 92.65 & 0.5 & 76.01 & 61.25 \\
\hline
\end{tabular}

\section{Temperature reduction and Saturation efficiency:}

Hourly cooling potential in terms of temperature reduction and saturation efficiency for the pad-fan and misting systems at different treatments is illustrated in Figures 4 and 5. A slight diurnal trend for the temperature reduction and saturation efficiency were found with a high cooling effect for the $207 \mathrm{kPa}$ nozzles pressure in misting system compared to other treatments. Almost the same cooling effect was found for the $5 \mathrm{~cm}$ pad thickness and $103 \mathrm{kPa}$ nozzles pressure and at different air velocities. However the variation in the outside weather conditions in addition to the 
non-fixed air velocity - in turn the airflow rate - result in an unclear general trend for the temperature reduction and saturation efficiency. Average values of maximum and minimum cooling potential in terms of temperature reduction and saturation efficiency for the pad-fan and misting systems at different treatments are shown in Table 4.
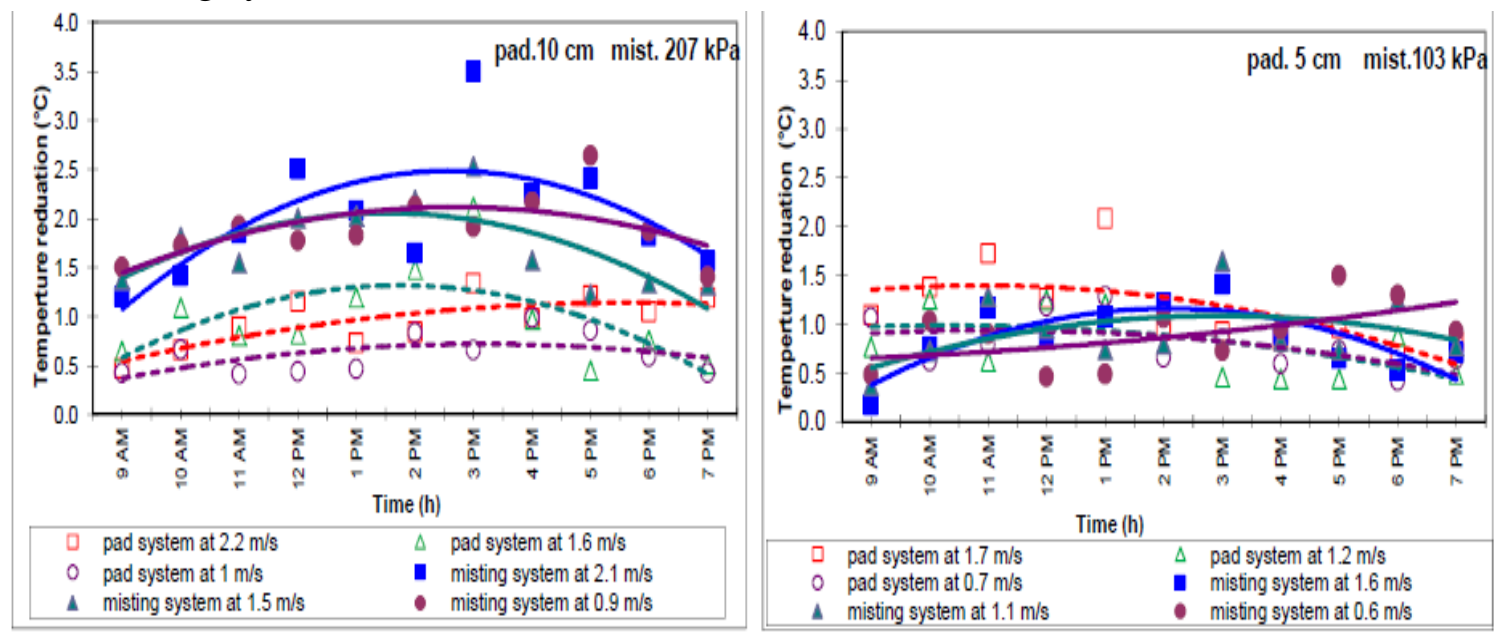

Figure 4: Hourly cooling potential in terms of temperature reduction for the pad-fan and misting systems at different treatments.
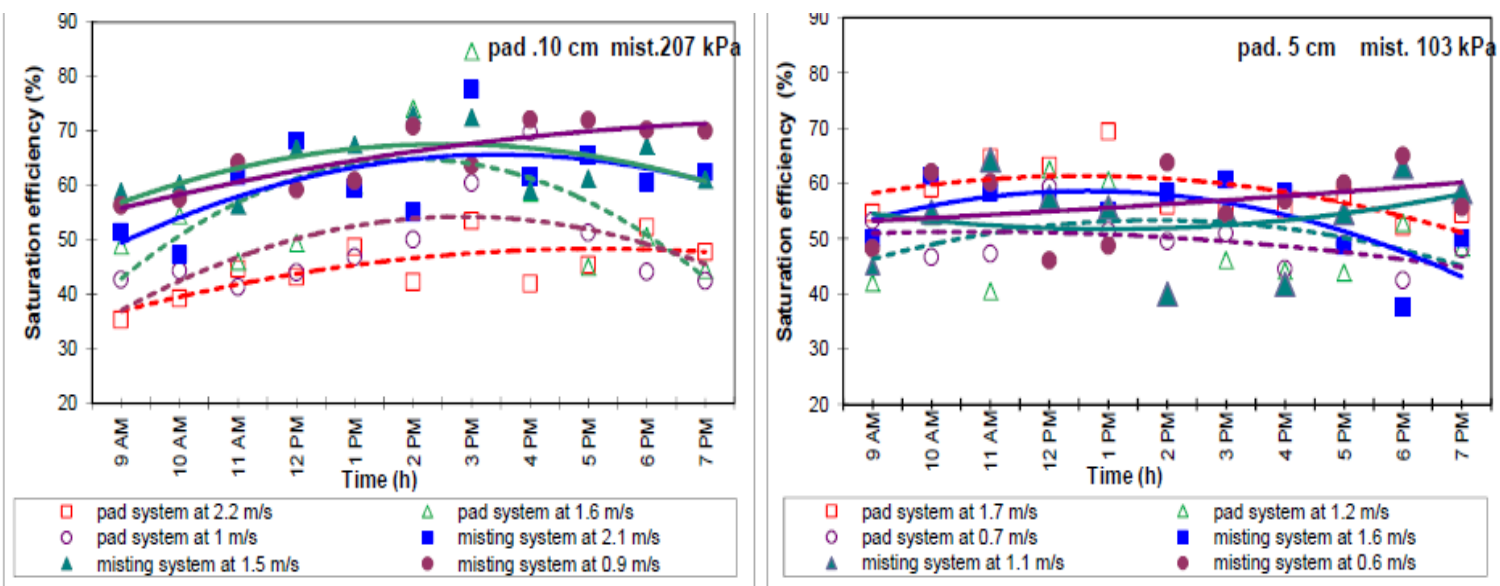

Figure 5: Hourly saturation efficiency for the pad-fan and misting systems at different treatments.

Generally a maximum temperature reduction beyond 2 and $3{ }^{\circ} \mathrm{C}$ for padfan and misting systems respectively was achieved. The high level of the outside air relative humidity $(81-95 \%)$ was an effective factor in this lower achieved cooling potential. Saturation efficiency ranged from 85 to 
$35 \%$ and from 78 to $38 \%$ for the pad-fan and misting system respectively. The lower levels of saturation efficiency refer basically to the high level of the outside air relative humidity as well.

Table 4: Average values of maximum and minimum cooling potential in terms of temperature reduction and saturation efficiency for the pad-fan and misting systems at different treatments.

\begin{tabular}{|c|c|c|c|c|c|c|c|c|c|c|c|}
\hline \multicolumn{6}{|c|}{ Pad- fan system } & \multicolumn{6}{|c|}{ Misting system } \\
\hline \multirow{2}{*}{$\begin{array}{l}\text { Pad } \\
\text { thickness } \\
\text { (cm) }\end{array}$} & \multirow[t]{2}{*}{$\begin{array}{c}\text { Air } \\
\text { velocity } \\
(\mathrm{m} / \mathrm{s})\end{array}$} & \multicolumn{2}{|c|}{$\begin{array}{c}\text { Temperature } \\
\text { reduction }(\Delta \mathbf{T}) \text {, } \\
\left({ }^{\circ} \mathbf{C}\right)\end{array}$} & \multicolumn{2}{|c|}{$\begin{array}{c}\text { Saturation } \\
\text { efficiency (SE), } \\
(\%)\end{array}$} & \multirow{2}{*}{$\begin{array}{c}\text { Nozzle } \\
\text { pressure } \\
(\mathrm{kPa})\end{array}$} & \multirow{2}{*}{$\begin{array}{c}\text { Air } \\
\text { velocity } \\
(\mathbf{m} / \mathbf{s})\end{array}$} & \multicolumn{2}{|c|}{$\begin{array}{c}\text { Temperature } \\
\text { reduction }(\Delta \mathrm{T}) \text {, } \\
\left({ }^{\circ} \mathrm{C}\right)\end{array}$} & \multicolumn{2}{|c|}{$\begin{array}{c}\text { Saturation } \\
\text { efficiency(SE), } \\
(\%)\end{array}$} \\
\hline & & Max & Min & Max & Min & & & Max & Min & Max & Min \\
\hline \multirow{3}{*}{10} & 2.2 & 1.34 & 0.47 & 53 & 35 & \multirow{3}{*}{207} & 2.1 & 3.49 & 1.20 & 78 & 47 \\
\hline & 1.6 & 2.12 & 0.45 & 85 & 44 & & 1.5 & 2.54 & 1.23 & 73 & 56 \\
\hline & 1 & 0.99 & 0.41 & 70 & 41 & & 0.9 & 2.64 & 1.40 & 72 & 56 \\
\hline \multirow{3}{*}{5} & 1.7 & 2.10 & 0.70 & 69 & 52 & \multirow{3}{*}{103} & 1.6 & 1.41 & 0.17 & 61 & 38 \\
\hline & 1.2 & 1.30 & 0.40 & 62 & 41 & & 1.1 & 1.65 & 0.38 & 64 & 40 \\
\hline & 0.7 & 1.30 & 0.40 & 59 & 42 & & 0.6 & 1.50 & 0.46 & 65 & 46 \\
\hline
\end{tabular}

\section{Specific temperature reduction $(\Delta T / Q)$ :}

Because of the non-fixed applied air velocity or in other words airflow rate levels a parameter relates the temperature reduction per a unit volumetric airflow rate namely specific temperature reduction $(\Delta \mathrm{T} / \mathrm{Q})$ was suggested. The maximum and minimum values of specific temperature reduction $(\Delta T / \mathrm{Q})$ for both evaporative cooling systems at different treatments are illustrated in Table 5. Generally the misting system had a superior effectiveness in terms of specific temperature reduction. However one should not deny the mathematical role for the lower values of airflow rates (the denominator) belong to this system. Pad thickness and airflow rate - as a function of - air velocity have an interaction effect on cooling effectiveness. Increasing pad thickness may need to increase air velocity in turn its kinetic energy to overcome airflow resistance due to pad material thickness. Simultaneously a sufficient contact time should be existed during which the air stream would be able to evaporate and carry water vapor particles.

However, more comprehensive investigation should be fulfilled on the present used pad material (mixture of rice straw and palm leaf fibers) to stand on its specific performance criteria. Regarding misting system, maximum and minimum specific temperature reduction decreased by 
increasing airflow rate in terms of increasing air velocity. In addition, the higher the nozzle pressure is the higher the specific temperature reduction. In general the specific temperature reduction ranged from 3.0 to $26.3{ }^{\circ} \mathrm{C} . \mathrm{s} / \mathrm{m}^{3}$ and from 1.5 to $41.5{ }^{\circ} \mathrm{C} . \mathrm{s} / \mathrm{m}^{3}$ for pad-fan system and misting system respectively.

Table 5: Maximum and minimum values of specific temperature reduction $(\Delta \mathrm{T} / \mathrm{Q})$ for both evaporative cooling systems at different treatments.

\begin{tabular}{|c|c|c|c|c|c|c|c|c|c|}
\hline \multicolumn{5}{|c|}{ Pad system } & \multicolumn{5}{|c|}{ Misting system } \\
\hline \multirow{2}{*}{$\begin{array}{c}\text { Pad } \\
\text { thickness } \\
(\mathbf{c m})\end{array}$} & \multirow{2}{*}{$\begin{array}{c}\text { Air } \\
\text { velocity } \\
(\mathbf{m} / \mathbf{s})\end{array}$} & \multirow{2}{*}{$\begin{array}{c}\text { Airflow } \\
\operatorname{rate}(Q) \\
\left(\mathbf{m}^{3} / \mathbf{s}\right)\end{array}$} & \multicolumn{2}{|c|}{$\begin{array}{c}(\Delta \mathrm{T} / \mathrm{Q}) \\
\left({ }^{\circ} \mathrm{C} . \mathrm{s} / \mathbf{m}^{3}\right)\end{array}$} & \multirow{2}{*}{$\begin{array}{c}\text { Nozzle } \\
\text { pressure } \\
(\mathbf{k P a})\end{array}$} & \multirow{2}{*}{$\begin{array}{c}\text { Air } \\
\text { velocity } \\
(\mathbf{m} / \mathbf{s})\end{array}$} & \multirow{2}{*}{$\begin{array}{c}\text { Airflow } \\
\text { rate }(\mathbf{Q}) \\
\left(\mathbf{m}^{3} / \mathbf{s}\right)\end{array}$} & \multicolumn{2}{|c|}{$\begin{array}{c}(\Delta \mathrm{T} / \mathbf{Q}) \\
\left({ }^{\circ} \mathbf{C} . \mathbf{s} / \mathbf{m}^{3}\right)\end{array}$} \\
\hline & & & Max & Min & & & & Max & Min \\
\hline \multirow{3}{*}{10} & 2.2 & 0.155 & 8.6 & 3.0 & \multirow{3}{*}{207} & 2.1 & 0.148 & 23.6 & 8.1 \\
\hline & 1.6 & 0.113 & 18.7 & 3.9 & & 1.5 & 0.106 & 23.9 & 11.6 \\
\hline & 1.0 & 0.071 & 14.0 & 5.8 & & 0.9 & 0.064 & 41.5 & 22.0 \\
\hline \multirow{3}{*}{5} & 1.7 & 0.120 & 17.5 & 5.8 & \multirow{3}{*}{103} & 1.6 & 0.113 & 12.5 & 1.5 \\
\hline & 1.2 & 0.085 & 15.3 & 4.7 & & 1.1 & 0.078 & 21.4 & 4.9 \\
\hline & 0.7 & 0.049 & 26.3 & 8.1 & & 0.6 & 0.042 & 35.4 & 10.9 \\
\hline
\end{tabular}

Figure 6 illustrates daily average of specific temperature reduction as affected by air velocity for both pad-fan and misting systems at various treatments. A damping effect of increasing air velocity is clear due to the predominant impact of the airflow rate.
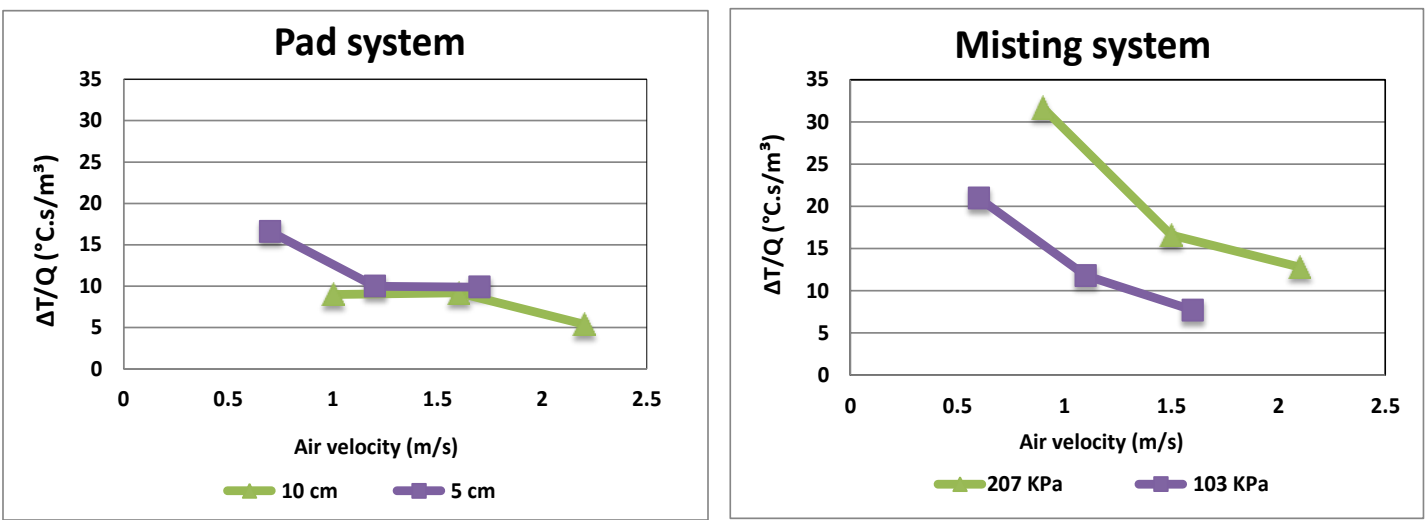

Figure 6: Daily average of specific temperature reduction as affected by air velocity for both pad-fan and misting systems at various treatments. 
Lower pad thickness $(5 \mathrm{~cm})$ needs low air velocity and the higher one (10 $\mathrm{cm}$ ) may need a moderate air velocity. For misting system a virtual and stronger effect of air velocity on the specific temperature reduction was occurred. This may refers to increasing the capability of air stream to prevent the accumulation of water droplets by increasing air velocity. Such an action enhances more water evaporation and in turn increases cooling effectiveness in terms of temperature reduction. On the other hand as it was expected the high level of nozzle pressure contributes in forming smaller water droplets which enhances the evaporation as well.

\section{Evaporative Cooler Performance Unit (Unit ECP):}

To judge the effectiveness of the evaporative cooling systems from the remove cooling load point of view the unit evaporative cooling performance (Unit ECP) was determined. The maximum and minimum values of Unit ECP for both evaporative cooling systems at different treatments are indicated in Table 6. Generally for the present study it was revealed an almost similar Unit ECP for both pad-fan and misting systems .In addition increasing pad thickness increases the maximum and minimum values of Unit ECP for fan-pad system and the same trend was found regarding nozzle pressure for misting system. Increasing air velocity or in other words airflow rate leads to an increase in the maximum and minimum values of Unit ECP for both systems. Daily average of Unit ECP as affected by air velocity for both pad-fan and misting systems at various treatments was shown in Figure 7. The direct positive relationship between air velocity and Unit ECP for both systems is very clear. However the variation in psychometric properties of the outside air at corresponding to both systems at different treatments may have some effect. Despite of the higher value of Saturation efficiency for pad system apparent when using $10 \mathrm{~cm}$ pad thickness and $1.6 \mathrm{~m} / \mathrm{s} \mathrm{pad}$ face air velocity, this value corresponding to the lowest Unit ECP increased by increasing thickness from ECP at the same specifications. This is due to the lowest airflow rate which was $0.113 \mathrm{~m}^{3} / \mathrm{s}$ for the mentioned treatment. It was strongly resulted misting system is the preferred system depending on the value of Unit ECP $10.7 \mathrm{~kW} /{ }^{\circ} \mathrm{C}$ at 2.1 $\mathrm{m} / \mathrm{s}$ air velocity was with the nozzles pressure $207 \mathrm{kPa}$ if compared with the high value of Unit ECP in pad system. 
Table 6: The average unit evaporative cooler performance (Unit ECP) for both pad system and misting system at various pad thicknesses and nozzles pressure under different air velocities

\begin{tabular}{|c|c|c|c|c|c|c|c|}
\hline \multicolumn{8}{|c|}{ Inside conditions } \\
\hline \multicolumn{4}{|c|}{$\begin{array}{l}\text { Pad- fan system } \\
\end{array}$} & \multicolumn{4}{|c|}{ Misting system } \\
\hline \multirow{2}{*}{$\begin{array}{c}\text { Pad } \\
\text { thickness } \\
(\mathrm{cm})\end{array}$} & \multirow{2}{*}{$\begin{array}{c}\text { Air } \\
\text { velocity } \\
(\mathbf{m} / \mathbf{s})\end{array}$} & \multicolumn{2}{|c|}{$\begin{array}{c}\text { Unit ECP } \\
\left(\mathrm{kW} /{ }^{\circ} \mathrm{C}\right)\end{array}$} & \multirow{2}{*}{$\begin{array}{c}\text { Nozzles } \\
\text { pressure } \\
\text { (kPa) }\end{array}$} & \multirow{2}{*}{$\begin{array}{c}\text { Air } \\
\text { velocity } \\
(\mathbf{m} / \mathbf{s})\end{array}$} & \multicolumn{2}{|c|}{$\begin{array}{c}\text { Unit ECP } \\
\left(\mathbf{k W} /{ }^{\circ} \mathbf{C}\right)\end{array}$} \\
\hline & & $\operatorname{Max}$ & Min & & & $\operatorname{Max}$ & Min \\
\hline \multirow{3}{*}{10} & 2.2 & 7.88 & 4.91 & \multirow{3}{*}{207} & 2.1 & 10.70 & 6.30 \\
\hline & 1.6 & 8.93 & 4.48 & & 1.5 & 7.20 & 5.40 \\
\hline & 1.0 & 4.52 & 2.67 & & 0.9 & 4.20 & 3.16 \\
\hline \multirow{3}{*}{5} & 1.7 & 7.59 & 5.59 & \multirow{3}{*}{103} & 1.6 & 6.26 & 3.79 \\
\hline & 1.2 & 4.85 & 3.14 & & 1.1 & 4.52 & 2.91 \\
\hline & 0.7 & 2.65 & 1.86 & & 0.6 & 2.43 & 1.77 \\
\hline
\end{tabular}

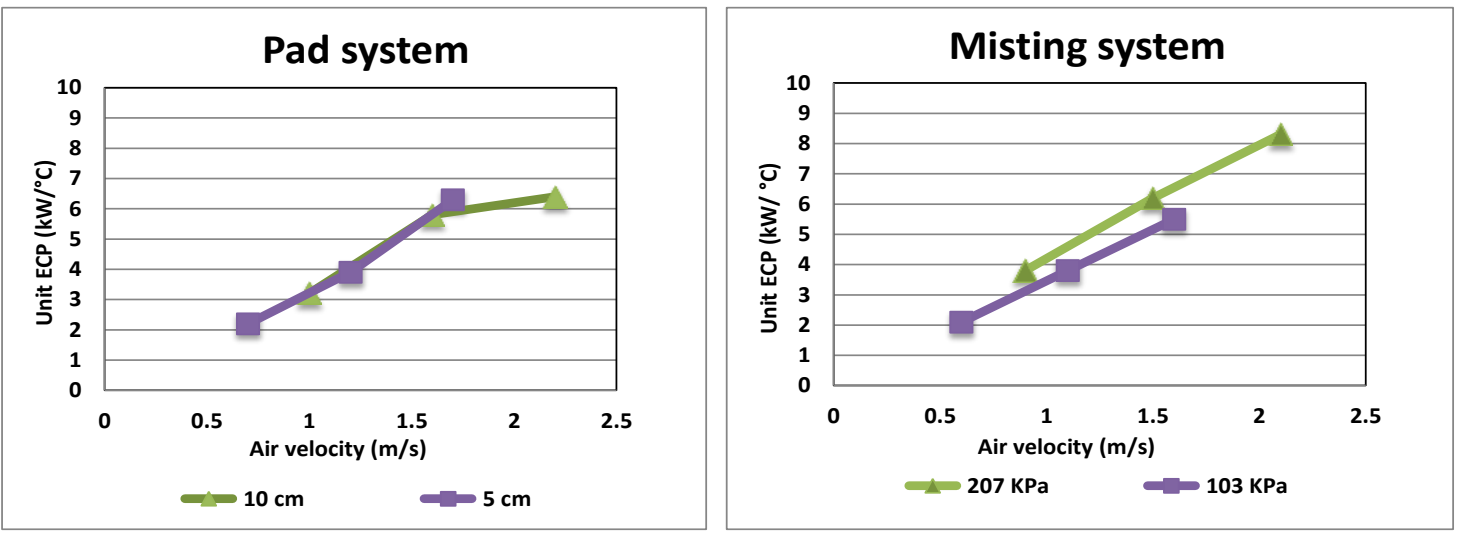

Figure 7: Daily averages of unit evaporative cooler performance (Unit ECP) for both pad system and misting system at various pad thicknesses and nozzles pressure under different air velocities

\section{Water consumption:}

Hourly rate of water consumption as affected by air velocity for both evaporative cooling system is indicated in Figure 8. The indicated values were calculated as a hourly average throughout operating periods. Water consumption increases with the increase of air velocity. The higher the pad thickness and nozzles pressure the higher is water consumption. This is due to, increasing surface area of water evaporation because of increasing pad thickness and regarding pad- fan system and decreasing water droplets diameter, in turn surface area regarding the missing system. For misting system the least water consumption was $4.4 \mathrm{~L} / \mathrm{h}$ at 
air velocity $1.1 \mathrm{~m} / \mathrm{s}$ with nozzles pressure $103 \mathrm{kPa}$. On the other hand, the pad system had higher water consumption $44.4 \mathrm{~L} / \mathrm{h}$ at air velocity $2.2 \mathrm{~m} / \mathrm{s}$.
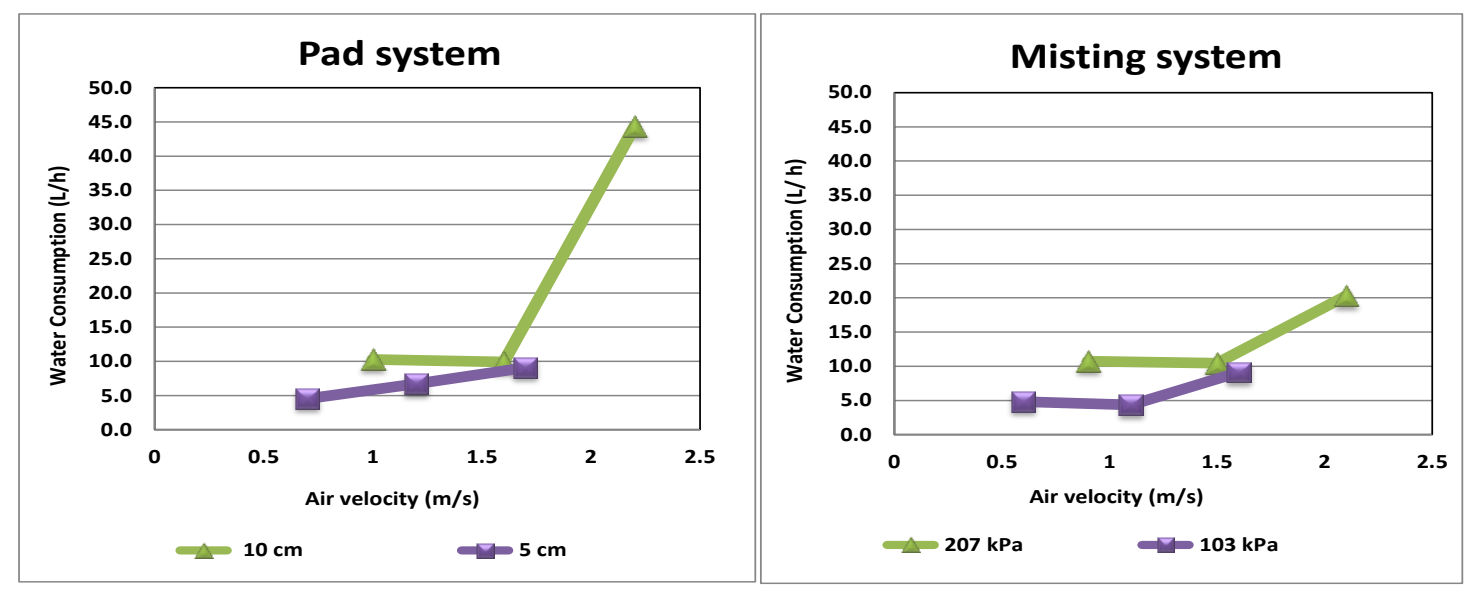

Figure 8: Hourly rate of water consumption as affected by air velocity for both evaporative cooling system at different ranges air velocities.

\section{CONCLUSION}

The study had been concentrated on two different evaporative cooling systems (pad-fan cooling, misting cooling) and compared with artificial ventilation system at different ranges air velocities. Based on the present study, it is observed that the misting system have been continuously achieved better cooling performance at pressure $207 \mathrm{kPa}$ and air velocity $2.1 \mathrm{~m} / \mathrm{s}$. This is based on their results as it gave $78 \%, 88.90 \%, 3.49{ }^{\circ} \mathrm{C}$ and $10.7 \mathrm{~kW} /{ }^{\circ} \mathrm{C}$ as saturation efficiency, relative humidity, temperature reduction and Unit ECP if compared with pad system values. Also it achieved $41.5^{\circ} \mathrm{C} . \mathrm{s} / \mathrm{m}^{3}$ as the highest specific temperature reduction at air velocity $0.9 \mathrm{~m} / \mathrm{s}$ and the least water consumption $4.4 \mathrm{~L} / \mathrm{h}$ at air velocity $1.1 \mathrm{~m} / \mathrm{s}$ with nozzles pressure $103 \mathrm{kPa}$. On other hand pad-fan system achieved the lower cooled air temperature $25.18{ }^{\circ} \mathrm{C}$ at pad thickness of $5 \mathrm{~cm}$ and $1.6 \mathrm{~m} / \mathrm{s}$ and the highest saturation efficiency $85 \%$ at $1.6 \mathrm{~m} / \mathrm{s}$ and pad thickness $10 \mathrm{~cm}$ but it as evaporative cooling system also increased relative humidity to the high value $98.6 \%$ and high water consumption $44.4 \mathrm{~L} / \mathrm{h}$ at air velocity $2.2 \mathrm{~m} / \mathrm{s}$.

\section{REFERENCES}

Abdallah S. E and M. A. Basiouny (2008) Influence of pad onfiguration on evaporative cooling system effectiveness inside a wind tunnel. 
The 15th. Annual Conference of the Misr Society of Ag. Eng., 1213 March, 2008. 591-613

Darwesh، M. ; S. Abouzaher ; T. Fouda and M. Helmy (2007). Effect of using pad manufactured from agricultural residues on the performance of evaporative cooling system. Misr J. Ag. Eng., 24(4):1023- 1043

Dayioğlu, M. A., and H. H. Silleli. (2015). Performance analysis of a greenhouse fan-pad cooling system: gradients of horizontal temperature and relative humidity. Journal of Agricultural Sciences, 21(1): 132-143.

Heidarinejad .G ; M. R. A .Moghaddam and H. Pasdarshahri (2019). Enhancing COP of an air-cooled chiller with integrating a water mist system to its condenser: Investigating the effect of spray nozzle orientation. International Journal of Thermal Sciences . (137) $508-525$

López‘ A. ; D. L. Valera; F. D. Molina-Aiz and A. Peña (2013). Effectiveness of horizontal air flow fans supporting natural ventilation in a Mediterranean multi-span greenhouse . Sci. Agric. v.70, n.4, p.219-228

Misra, D., and S. Ghosh. (2017). Performance study of a floricultural greenhouse surrounded by shallow water ponds. International Journal of Renewable Energy Development, 6(2):137-144.

Misra, D., and S. Ghosh.( 2018). Evaporative cooling technologies for greenhouses: a comprehensive review. Agric Eng Int: CIGR Journal, Vol. (20), No. (11).

Shah, B.A. (2015) . Performance Investigation of Evaporative Cooling Pads of Different Materials. National Conference on Innovative and Emerging Technologies, At SR Patel Engineering College, Unjha, Vol. 1

Shen, T., and C. Chen. (2012). Misting cooling technique for protected culture of Oncidium orchids in subtropical regions . Afr. J. Biotechnol.11(80): 14612 -14620

Tayel, S. A.; M. A. Mosallam and A. M. Mousa. (2010). Evaluation of three evaporative cooling pads from agricultural wastes. Misr J. Eng., 27(3):924 - 942

Website: https://hvac-library.blogspot.com/p/digital-psychrometric-chart.html (accessed on 2015) 


\section{الملخص العربى \\ فاعلية نظامين تبريد تبخيري في حيز هوائي دافئ مصطنع

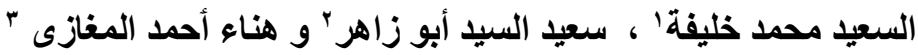

يعد الإجهاد الحراري داخل المنشآت الزر اعية مثل مزارع الإنتاج الحيواني و الداجنى بالإضافة

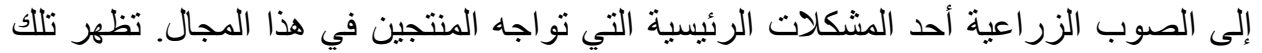

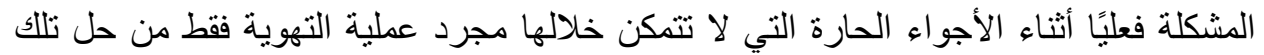
المشكلة . تعمل أنظمة التبريد التبخيري على التخفيف من الإجهاد الحراري واءئ المساهمة في تهيئة

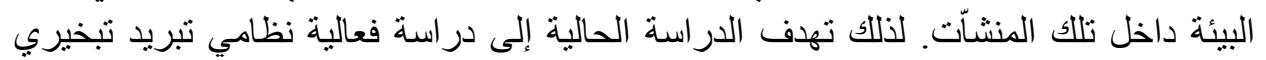

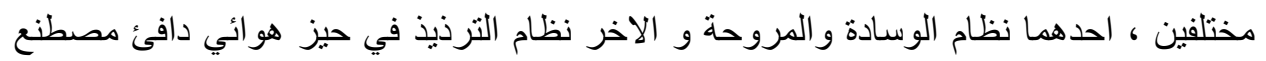

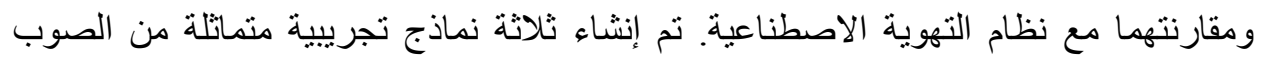

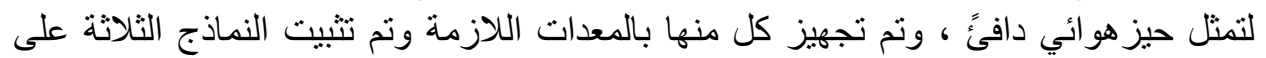

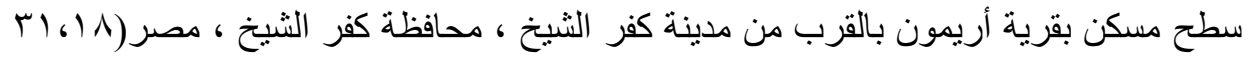

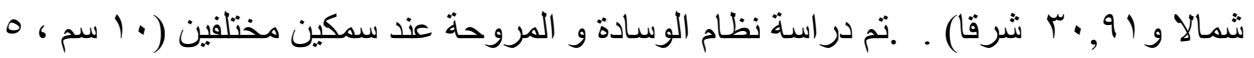

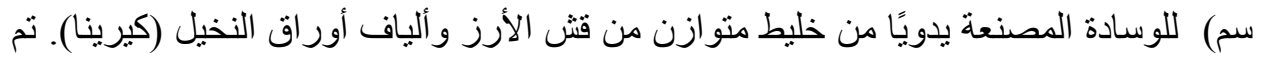

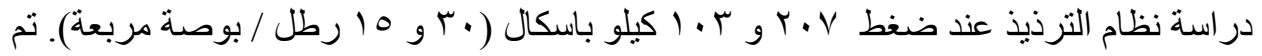

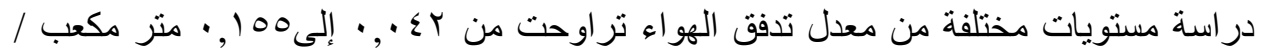

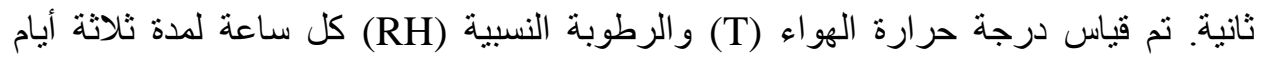

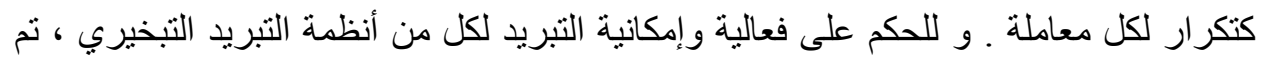

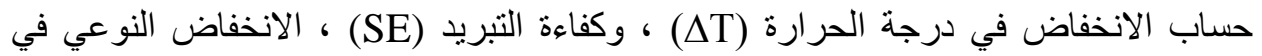
درجات الحرارة (UT/Q) ، أداء وحدة التبريد التبخيري ( Unit ECP) واستهلاك المياه . .

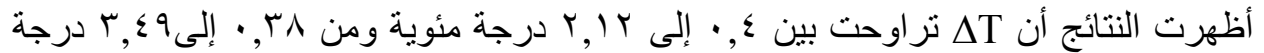

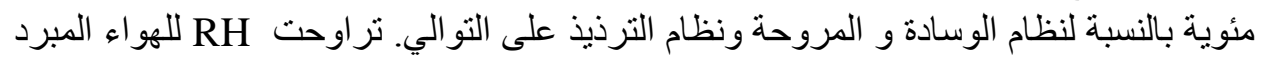

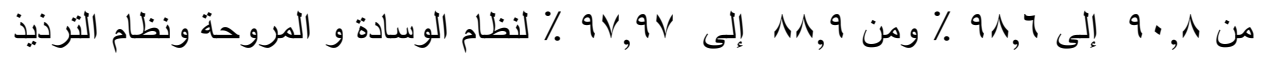

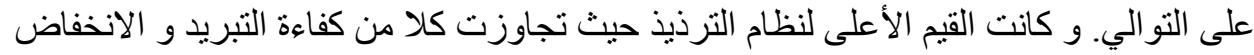

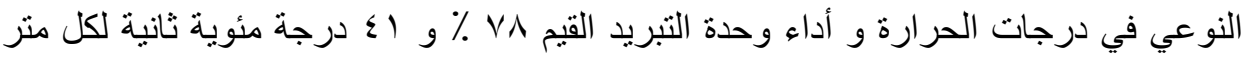

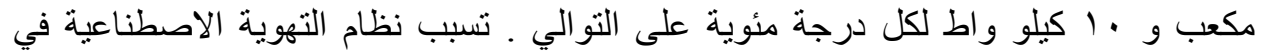

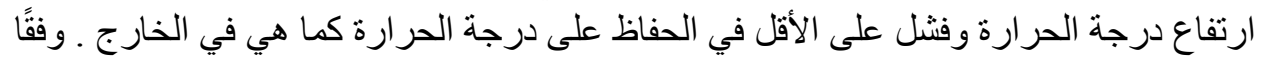
للظروف التجريبية الحالية ، اثبت نظام الترذيذ فعالية في عملية التبريد ، كذلك حقق توفير التي في استهلاك المياه و هذا بالاضافة الى ان هذا النظام ذو اهمية في تكنولوجيا الري في الزراعة فئة

المحمية.

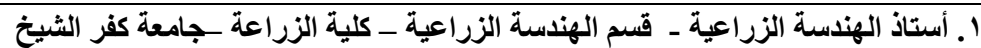

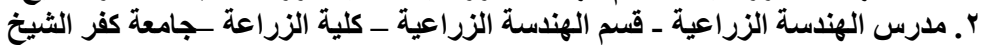

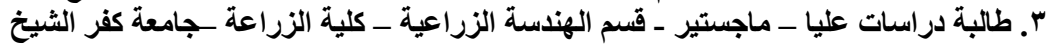

